\title{
The Public-Private Distinction in Global Governance: How Relevant is it in the Case of Voluntary Sustainability Standards?
}

\author{
Axel Marx
}

Leuven Centre for Global Governance Studies, University of Leuven, Belgium axel.marx@ggs.kuleuven.be

\begin{abstract}
Whether global rules and standards originate from a public intergovernmental body or from a private organization has significant implications for the applicability of international law such as wTo law. However, how sensible is this distinction between public and private? This paper argues that the distinction between public and private standards only makes sense if one looks at the legal status of specific standard-setting organisations. However, the distinction between public and private begins to blur and fade if one switches the unit of analysis. First, the paper shows that private standards are often based on internationally agreed (public) rules and norms. Second, the paper argues that governments on purpose or in the design of their policies take these private initiatives on board. Hence, they become an integral part of 'public' governance. These arguments are developed on the basis of an analysis of Voluntary Sustainability Standards (vss).
\end{abstract}

\section{Keywords}

standards - Voluntary Sustainability Standards - certification - international trade and global governance

* The author thanks the participants in the conference on "Private Standards and (Transatlantic) Trade Integration" European University Institute, Florence, November 10-11, 2014 for stimulating discussions and feedback. 
Every October the world celebrates 'standards day'. This day, organized by the International Organization for Standardization (ISO), intends to pay tribute to the role voluntary standards play in society. In 2014 standards day was devoted to 'levelling the playing field' and underlined the importance of international standards to stimulate trade. Obviously, standards can also constitute barriers to trade and distort the playing the field. Either way, standards increasingly play an important role in economic relations. ${ }^{1}$ For example, in South Korea, one of the most spectacular examples of post-war economic development and industrialization, the number of standards governing and regulating industry has increased exponentially. The Korean Agency for Technology and Standards (KATS), the main body for developing standards, developed 300 standards by 1962. This increased to $855^{2}$ in 1990 and 23923 in $2011 .^{2}$

However, not only technical standards stipulating products requirements or interoperability requirements are being developed but also standards on a whole range of issues such as, quality management standards to organize management, environmental management standards to reduce environmental impacts, health and safety standards to reduce accidents in the workplace, food safety standards to prevent food from being contaminated, energy management standards to cut energy consumption and human rights and labor standards. These standards are developed by a diverse set of actors ranging from governmental and intergovernmental organizations to individual firms and NGOs. In their 'governance triangle' Abbott and Snidal ${ }^{3}$ identified three main actors in transnational regulatory standard-setting activities. They subdivide the standard-setting initiatives on the basis of the actors involved in standard-setting process. They distinguish between three major actors, the state, firms and non-governmental organisations. These three actors form the 'governance triangle'. Within this triangle, they distinguish seven zones, depending on how many parties are involved in the standard-setting process. Three zones contain initiatives in which one party (either state, firm or NGO) develops the standards, three zones contain initiatives in which a combination

1 Busch, L. (2013) Standards: Recipes for Reality. Mass: MIT Press.

2 Andreosso-O'Callaghan, B. (2013) 'The EU-Korea FTA and the Relaxation of Regulaotry Measures in the Mechanical Engineering Industry', pp. 105-120, in Marx, A. et al. (eds.) EU-Korea Relations in a Changing World. Leuven: Leuven Centre for Global Governance Studies.

3 Abbott, K. W. and Snidal, D. (2009), 'Strengthening International Regulation Through Transnational New Governance: Overcoming the Orchestration Deficit', Vanderbilt Journal of Transnational Law, 42, 2, pp. 501-578. 
of two parties develop standards, and one zone contains standard-setting initiatives which are developed by the three parties.

This classification makes already clear that not only states are involved in setting standards, but also non-state actors. 'Private' actors are increasingly developing and enforcing standards. This distinction between public and private in terms of who sets the standards can have important implications. As Mavroidis and Wolfe ${ }^{4}$ point out in the context of the WTO it makes a significant difference of whether standards are 'private' or 'public' in terms of the applicability of wTо law. Public standards fall under wTо, while 'private' standards do not. However, how sensible is this distinction between public and private?

This paper argues that the distinction between public and private only make sense if one looks at the legal status of specific standard-setting organisations. However, the distinction between public and private begins to blur and fade if one switches the unit of analysis. In this context, two different unit of analysis are of importance. One unit of analysis focuses on specific standards, while another unit of analysis looks at a more aggregated level and analyzes broader 'public' regulatory approaches in which private standards are embedded. Concerning the former, the paper shows that private standards are often based on internationally agreed (public) rules and norms. Concerning the latter, the paper argues that governments on purpose or in the design of their policies take these private initiatives on board. Hence, they become an integral part of 'public' governance. These arguments are developed on the basis of an analysis of Voluntary Sustainability Standards (vss), which constitute a leading example of so-called private standards. ${ }^{5}$ The paper first introduces the emergence, proliferation and importance of vss. Next, the paper assesses how private standards in vss. Then our attention turns to the link between public policy and vss. We end with a conclusion.

\section{2}

\section{Voluntary Sustainability Standards}

The United Nations Forum on Sustainability Standards (UNFSs) ${ }^{6}$ defines vss as "standards specifying requirements that producers, traders, manufacturers,

4 Mavroidis, P. \& R. Wolfe (2016) 'Private Standards and the WTO: Reclusive No More', in, EUI Working Paper RSCAS 2016/17.

5 Marx, A., Maertens, M., Swinnen, J. and J. Wouters (2012)(eds.) Global Governance and Private Standards. Interdisciplinary Perspectives. Cheltenham: Edward Elgar.

6 In the spring of 2013 the United Nations Forum on Sustainability Standards (UNFSS), a joint initiative by five UN agencies (FAO, UNIDO, ITC, UNEP and UNCTAD), was launched. The 
retailers or service providers may be asked to meet, relating to a wide range of sustainability metrics, including respect for basic human rights, worker health and safety, the environmental impacts of production, community relations, land use

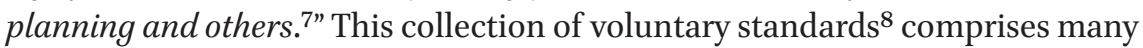
different initiatives. Although some voluntary systems are governmental, most of them are private initiatives. The Ecolabel Index database counts more than $45^{\circ}$ initiatives. The international standards map of the International Trade Centre counts more than 16o. A few examples illustrate the diversity. Some initiatives are driven by industry (associations) or NGOs, such as Responsible Care in the chemical sector, the charter of employment rights of the clothing giant GAP, or the Clean Clothes Campaign, which strives to achieve better terms of employment in textile production plants in developing countries. Some initiatives that have generated significant academic interest are non-state multistakeholder sustainability certification initiatives. Among the most prominent and representative examples of these private regulatory initiatives are the Fairtrade Labelling Organization (FLO), the Forest Stewardship Council (FSC), the Fair Labour Association (FLA), Social Accountability International (SAI) and the Marine Stewardship Council (MSC). The FLO, established in 1997, was founded to enable producers and workers in developing countries to evolve from a position of vulnerability to a position of economic security and self-sufficiency. The core of the system focuses on the concept of a fair price. The FSC, set up in 1993, is an international, multi-stakeholder, consensus-based sustainable forestry initiative. It guarantees that a wood or paper product has been made using material from a sustainably managed forest. SAI is a non-governmental, international, multi-stakeholder and non-profit organization whose mission is to promote the rights of workers worldwide and to improve working conditions by applying socially responsible standards. The F LA grew out of the Apparel Industry Partnership (AIP) initiative of the Clinton administration to protect workers worldwide and provide firms and consumers with the information they need to make informed purchasing decisions. The partnership

UNFSS is a platform created to generate knowledge and information on voluntary sustainability standards (vss) with a particular focus on their potential contribution to development.

7 UNFSS (2013) Voluntary Sustainability Standards. Today's landscape of issues and initiatives to achieve public policy objectives. United Nations Forum on Sustainability Standards, p. 3.

8 There is no general agreed upon specific definition of a standard. According to Iso (ISO/ IEC Guide 2:1996, definition 3.2) a standard is "a document, established by consensus and approved by a recognized body, that provides, for common and repeated use, rules, guidelines or characteristics for activities or their results, aimed at the achievement of the optimum degree of order in a given context." 
was composed of apparel and footwear firms, human rights groups, labor and religious organizations, and consumer advocates. The FLA now represents a multi-stakeholder coalition of business enterprises, colleges and universities, and NGOs (human rights, labor, religious and consumer groups). Its mission is to combine the efforts of these stakeholders to promote adherence to international labor standards and improve labor rights worldwide. GLOBALG.A.P is one of the many, but leading vss in agriculture and certifies farms according to a set of good agricultural practices which include health and safety issues and social and environmental issues. A final example is the MSC, which grew out of a partnership between WWF and Unilever and which aims to sustainable manage oceans and fisheries. In almost every economic sector, vss are currently active and operate internationally.

The various initiatives differ from one another. Most initiatives, however, are characterized by the fact that an organization defines social and environmental standards and that there is a procedure to check that products or production processes conform to these standards (i.e. conformity assessment). The standard setting often occurs in specific decision-making bodies within the vss organizations, which are (should be) open to multiple stakeholders. This stakeholder involvement might imply that special procedures are set in place to involve stakeholders in defining and operationalizing standards. These procedures can include the identification of stakeholders via stakeholder mapping; the development of a strategy to proactively approach and involve the identified stakeholders; the bringing together of several major stakeholders on a more or less equal representative basis in a decision-making; the opening up of the decision-making process to all interested parties not initially identified in the first round of the stakeholder mapping; and the deployment of consensus-based decision making in order to ensure that all interests are included. ${ }^{9}$ In essence, any person (organization, company, government agency, individual, etc.) with an interest has in principle a right to participate in the standardsetting process.

Once standards are developed vss put systems in place to assess conformity with standards and monitor compliance with standards by rule-takers. In the context of vss, conformity assessment and monitoring are key components since they form the backbone of the enforcement architecture of vss. Monitoring is a control-mechanism that allows for the assessment of the compliance with standards. Monitoring in vss is a function of two interrelated aspects, namely monitoring and the presence of complaint

9 ISEALAlliance (2010) ISEAL Code of Good Practice for Setting Social and Environmental Standards. London: ISEALAlliance. 
systems ${ }^{10}$ Monitoring refers to the assessment of conformity with standards by independent third parties based on auditing protocols. The conformity of products and processes to standards must be assessed and demonstrated to gain certification. In order to provide assurance that parties which carry out conformity assessments and certification activities are fitted for the task, accreditation systems are sometimes put in place. Accreditation aims to guarantee that a conformity assessment body is competent to carry out such tasks as auditing and inspection, and to come to the right conclusion as to whether a product complies with a defined standard. Accredited organizations are often international consultancy firms such as SGS and Bureau Veritas. ${ }^{11}$ Hence monitoring involves an independent certification body, which performs the conformity assessment. With regard to the certification of social and environmental standards monitoring/conformity assessment takes the form of auditing sites according to an auditing protocol. ${ }^{12}$ Auditing systems, however, are incomplete for monitoring standards. ${ }^{13}$ In order to overcome the limitations of monitoring based on auditing, complaint or dispute settlement procedures are set in place, which allows different stakeholders to constantly monitor and report any violations of standards.

The emergence of these vss is sparked by many interrelated factors and the story about their emergence is also partially different depending on the commodities covered and the type of vss. First of all, consumers have grown more conscious of social and environmental issues and may adjust their purchasing behavior in relation to the perceived sustainability of products. ${ }^{14}$ In order to cater for this market special points of recognition such as labels, based on vss, were developed. Second, brand protection is a key issue for many leading companies. Changing strategies of NGOs that directly target firms through the use of media campaigns and boycotts, have forced firms to take civil society

10 Marx, A. \& J. Wouters (2016) 'Redesigning enforcement in private labor regulation. Will it work?', in, International Labor Review.

11 Blair, M. Williams, C. \& L. Lin (2008) 'The New Role for Assurance Services in Global Commerce', in, Journal of Corporation Law, 33, 2, pp. 325-360.

12 For a critical discussion see Marx, A. \& J. Wouters (2016) 'Redesigning enforcement in private labor regulation. Will it work?', in, International Labor Review.

13 Locke, R. (2013) The Promise and Limits of Private Power. Promoting Labor Standards in a Global Economy. Cambridge: Cambridge University Press; Marx, A. (2014a) 'Legitimacy, Institutional Design and Dispute Settlement. The Case of Eco-certification systems', in, Globalizations 11, 3, pp. 401-416.

14 O'Rourke, D. (2012) Shopping for Good. MIT Press. 
concerns into account. ${ }^{15}$ This has led firms to engage with NGOs and set up vss. For NGOs this collaboration also offered benefits. Rather than being confrontational towards firms or try to influence firm behaviour via lobbying governments, NGO's are using a co-operative strategy towards firms of which vss are prominent example. As Bartley notes "private efforts have also been perceived by many NGO's as a way to bypass political roadblocks" ${ }^{16}$ Thirdly, in some cases government regulation has been a driver of vss development. For example, the U K Food Safety Act of 1990 provided that food retailers had to govern their supply chain which resulted in the development of many different vss, first on the level of individual retailers followed by initiatives of consortia of retailers. ${ }^{17}$ Fourthly, many vss emerged as a reaction to other vss. For example, NGO driven vss are sometimes countered by industry driven vss or vice versa. Or several different NGO or industry vss operate in the same market. This dynamic has actually led to a proliferation of vss in which many competing vss operate in the same economic sector ${ }^{18}$ Finally, some initiatives emerged as empowerment and capacity building initiatives in the global South. ${ }^{19}$ The Fair Trade certificates are a good example of this type of vss. Their emergence has a different logic and set of drivers and is more rooted in the tradition of cooperatives and markets for cooperatives.

After their emergence and proliferation these vss have spread out globally following the internationalization and splintering of production lines and supply chains. ${ }^{20}$ There is little consolidated data available on the global adoption of vss. One way to approach this question is to analyze which systems are active in which countries. Here one uses the total field of vss as a unit of

15 Bartley, T. (2003) 'Certifying forests and factories: States, social movements, and the rise of private regulation in the apparel and forest products fields', Politics and Society 31 (3): 433-464; Gereffi G, Garcia-Johnson R., Sasser E. (2001), 'The NGO-Industrial Complex', Foreign Policy 125, 56-65.

16 Bartley, T. (2011) 'Certification as a mode of social regulation, in D. Levi-Faur (ed.) Handbook on the Politics of Regulation, Cheltenham: Edward Elgar, pp. 441-452 at p. 445.

17 Henson, S. and J. Humphrey (2012) 'Private Standards in global agri-food chains', pp. 98-113, in Marx et. al (eds.) Global Governance and Private Standards. Interdisciplinary Perspectives. Cheltenham: Edward Elgar.

18 Marx, A. \& J. Wouters (2015) 'Competition and Cooperation in the Market of Voluntary Standards Sustainability Standards', in, Delimatsis, P. (ed.) International standardization - Law, Economics and Politics. Cambridge: Cambridge University Press.

19 Auld, G., Renckens, S. \& B. Cashore (2014) 'Transnational private governance between the logics of empowerment and control', in, Regulation and Governance, doi:10.1111/rego.12075.

20 Hoekman, B. (2014) Supply Chains, Mega-Regionals and Multilateralism. A Road Map for the WTO. London: CEPR Press at p. 15 . 
analysis and assesses the degree to which they are active in a specific country. This approach will inform us which vss are active in which countries. However, it does not tell us much about the magnitude of adoption in a specific country of a specific vss. To analyze how many standards are active in a country we collected data from the International Trade Centre standards map, which contains data on more than 160 standards. Table 1 shows the number of vss active in a specific country and ranks the countries from high (countries with the most number of vss active) to low (countries with the lowest number of vss active).

TABLE $1 \quad$ Number of Vss per country

\begin{tabular}{|c|c|c|c|c|c|}
\hline \multirow[b]{2}{*}{$\mathbf{1}$} & \multirow[b]{2}{*}{ China } & \multicolumn{3}{|c|}{ \# Vss } & \multirow{2}{*}{$\begin{array}{c}\text { \# VSS } \\
47\end{array}$} \\
\hline & & 79 & 26 & Argentina & \\
\hline 2 & USA & 78 & 27 & Ecuador & 47 \\
\hline 3 & Brazil & 77 & 28 & Turkey & 47 \\
\hline 4 & India & 72 & 29 & Chile & 47 \\
\hline 5 & Mexico & 71 & 30 & Japan & 45 \\
\hline 6 & Canada & 70 & 31 & Poland & 45 \\
\hline 7 & United Kingdom & 70 & 32 & Portugal & 44 \\
\hline 8 & Netherlands & 69 & 33 & Malaysia & 44 \\
\hline 9 & Germany & 67 & 34 & Guatemala & 44 \\
\hline 10 & Belgium & 65 & 35 & Honduras & 44 \\
\hline 11 & Thailand & 65 & 36 & Finland & 43 \\
\hline 12 & Colombia & 64 & 37 & Kenya & 43 \\
\hline 13 & Indonesia & 64 & 38 & Sri Lanka & 43 \\
\hline 14 & Peru & 64 & 39 & Egypt & 43 \\
\hline 15 & Spain & 64 & 40 & Tanzania & 43 \\
\hline 16 & Denmark & 63 & 41 & Hungary & 43 \\
\hline 17 & France & 62 & 42 & Norway & 42 \\
\hline 18 & Italy & 62 & 43 & Czech Republic & 47 \\
\hline 19 & South Africa & 62 & 44 & Greece & 47 \\
\hline 20 & Viet Nam & $6 o$ & 45 & Ireland & 47 \\
\hline 21 & Costa Rica & 59 & 46 & Philippines & 47 \\
\hline 22 & Switzerland & 59 & 47 & Ghana & 45 \\
\hline 23 & Australia & $5^{8}$ & 48 & Uganda & 45 \\
\hline 24 & Austria & 57 & 49 & Dominican Rep & 44 \\
\hline 25 & Sweden & 57 & $5^{0}$ & New Zealand & 44 \\
\hline
\end{tabular}




\begin{tabular}{|c|c|c|c|c|c|}
\hline & & \# VSs & & & \# vss \\
\hline $5^{1}$ & Romania & 44 & 89 & Senegal & 30 \\
\hline $5^{2}$ & Slovenia & 44 & 90 & Panama & 29 \\
\hline 53 & Bolivia & 43 & 91 & Rwanda & 29 \\
\hline 54 & Bulgaria & 43 & 92 & Congo & 28 \\
\hline 55 & Ethiopia & 43 & 93 & Namibia & 28 \\
\hline $5^{6}$ & Latvia & 43 & 94 & Venezuela & 28 \\
\hline 57 & Morocco & 43 & 95 & Belize & 27 \\
\hline $5^{8}$ & Tunisia & 43 & 96 & Laos & 27 \\
\hline 59 & Madagascar & 42 & 97 & Lebanon & 27 \\
\hline 60 & Nicaragua & 42 & 98 & Saoudi Arabia & 26 \\
\hline 61 & Lithuania & 41 & 99 & Kazakstan & 26 \\
\hline 62 & Pakistan & 41 & 100 & Mali & 26 \\
\hline 63 & Singapore & 41 & 101 & TFRY Macedonia & 26 \\
\hline 64 & Slovakia & 40 & 102 & Albania & 25 \\
\hline 65 & Zambia & 40 & 103 & Iceland & 24 \\
\hline 66 & Estonia & 39 & 104 & Oman & 24 \\
\hline 67 & Russian Federation & 39 & 105 & Suriname & 24 \\
\hline 68 & Paraguay & 38 & 106 & Togo & 24 \\
\hline 69 & Zimbabwe & 38 & 107 & Algeria & 23 \\
\hline 70 & Croatia & 37 & 108 & Swaziland & 23 \\
\hline 71 & El Salvador & 37 & 109 & Bahrein & 22 \\
\hline 72 & Israel & 37 & 110 & Georgia & 22 \\
\hline 73 & Uruguay & 37 & 111 & Myanmar & 22 \\
\hline 74 & Bangladesh & 36 & 112 & Niger & 22 \\
\hline 75 & Cyprus & 36 & 113 & Trinidad and Tobago & 22 \\
\hline 76 & Mauritius & 36 & 114 & Azerbaijan & 21 \\
\hline 77 & Luxembourg & 35 & 115 & Benin & 21 \\
\hline 78 & Serbia & 35 & 116 & Botswana & 21 \\
\hline 79 & Ukraine & 35 & 117 & Burundi & 21 \\
\hline 80 & Cote d'Ivoire & 34 & 118 & Guinea & 21 \\
\hline 81 & United Arab Emirates & 34 & 119 & Iran & 21 \\
\hline 82 & Cambodia & 33 & 120 & Syrian Arab Republic & 21 \\
\hline 83 & Malawi & 33 & 121 & Afghanistan & 20 \\
\hline 84 & Mozambique & 32 & 122 & Armenia & 20 \\
\hline 85 & Cameroon & 31 & 123 & Cuba & 20 \\
\hline 86 & Papua New Guinea & 31 & 124 & Gambia & 20 \\
\hline 87 & Bosnia\&Herzegovina & 30 & 125 & Guyana & 20 \\
\hline 88 & Burkina Faso & 30 & 126 & Uzbekistan & 20 \\
\hline
\end{tabular}


TABLE $1 \quad$ Number of vss per country (cont.)

\begin{tabular}{|c|c|c|c|c|c|}
\hline & & \# vs & & & \# vss \\
\hline 127 & Angola & 19 & $15^{\circ}$ & Kyrgystan & 16 \\
\hline 128 & Korea DPR & 19 & 151 & Mauritania & 16 \\
\hline 129 & Solomon Islands & 19 & $15^{2}$ & Tajikistan & 16 \\
\hline 130 & Sudan & 19 & 153 & Vanuatu & 16 \\
\hline 131 & Turkmenistan & 19 & 154 & Yemen & 16 \\
\hline 132 & Fiji & 19 & 155 & Sierra Leone & 15 \\
\hline 133 & Gabon & 19 & $15^{6}$ & Djibouti & 14 \\
\hline 134 & Seychelles & 18 & 157 & Iraq & 14 \\
\hline 135 & Barbados & 17 & $15^{8}$ & Kiribati & 14 \\
\hline 136 & Kuwait & 17 & 159 & Maldives & 14 \\
\hline 137 & Lesotho & 17 & 160 & Somalia & 14 \\
\hline 138 & Liberia & 17 & 161 & Andorra & 13 \\
\hline 139 & Micronesia, Fed. & 17 & 162 & St Vincent and Grenadines & 13 \\
\hline 140 & Quatar & 17 & 163 & Cape Verde & 13 \\
\hline 141 & Samoa & 17 & 164 & Chad & 13 \\
\hline 142 & Timor-Leste & 17 & 165 & Comoros & 13 \\
\hline 143 & Antigua\&Baburda & 16 & 166 & Equatorial Guinea & 13 \\
\hline 144 & Bahamas & 16 & 167 & Libyan Arab & 13 \\
\hline 145 & Brunei Darussalam & 16 & 168 & New Caladonia & 13 \\
\hline 146 & $\begin{array}{l}\text { Central African } \\
\text { Republic }\end{array}$ & 16 & 169 & Palau & 13 \\
\hline 147 & Dominica & 16 & 170 & Bhutan & 12 \\
\hline 148 & Grenada & 16 & 171 & Eritrea & 12 \\
\hline 149 & Guinea-Bissau & 16 & 172 & Sao Tome Principe & 12 \\
\hline
\end{tabular}

The table reveals a few interesting observations. First of all, vss are active in almost every country in the world. Mostly missing are very small islands states or rough states such as North Korea. In general, vss cover the world. Second, there is significant variation between states. Some states are vss hotspots with many vss active, while in other only a few ones are active. The countries with many vss active are typically large industrialized countries but there are also some exceptions and some Middle Income Countries rank remarkably high (Colombia, Peru, Thailand). 
Besides their global reach vss generate a diverse set of effects, which are becoming increasingly well documented. Several studies have documented a plethora of impacts. Often studies focus on specific vss in specific countries. Overall one can identify many types of impacts, both positive as well as negative and intended and some unintended. A large number of impact studies focus on parameters related to profitability and economic benefits, including price premiums gained by participating in vss, increase in yield, quality or net income as well as costs incurred and finally market access. ${ }^{21}$ Some studies, specifically focus on organizational change and innovation generated by vss ${ }^{22}$ Besides impact on economic benefits some studies report social impacts on wages, gender equity, health and education, empowerment, social capital and labour conditions ${ }^{23}$

In sum, vss are an important transnational governance tool in the context of sustainable development with a global reach. As a result, they regulate

21 ITC (2011b) The Impacts of Private Standards on Producers in Developing Countries. In Literature Review Series on the Impacts of Private Standards; Part II. Geneva: International Trade Centre (ITC); ITC (2011a) The Impacts of Private Standards on Global Value Chains. In Literature Review Series on the Impacts of Private Standards; Part I. Geneva: International Trade Centre (ITC); Food and Agriculture Organization (2014) Impact of international voluntary standards on smallholder market participation in developing countries: a review of literature. Rome.

22 Cubbage F., Diaz D., Yapura P., Dube F. (2010) 'Impacts of forest management certification in Argentina and Chile' in, Forest Policy and Economics, 12, 7, pp. 497-504; Duchelle A. E., Kainer K. A., Wadt L. H. O. (2014) 'Is Certification Associated with Better Forest Management and Socioeconomic Benefits? A Comparative Analysis of Three Certification Schemes Applied to Brazil Nuts in Western Amazonia' in, Society \& Natural Resources, 27, 2, pp. 121-139.

23 Nelson, V. and A. Martin (2014) 'Final Technical Report: Assessing the Poverty Impact of Voluntary Sustainability Standards'. Natural Resources Institute Report, University of Greenwich: Chatham; Wiersum K. F., Humphries S., van Bommel S. (2013), Certification of community forestry enterprises: experiences with incorporating community forestry in a global system for forest governance in, 'Small-scale Forestry, 12, 1, pp. 15-31; Quaedvlieg J., Roca M. G., Ros-Tonen, M. A. F.(2014) 'Is Amazon nut certification a solution for increased smallholder empowerment in Peruvian Amazonia?' in, Journal of Rural Studies, 33, pp. 41-55; Pinto L. F. G., McDermott C. (2013) 'Equity and Forest Certification-A case study in Brazil' in, Forest Policy and Economics, 30, pp. 23-29; SOAs. (2014) Fairtrade, Employment and Poverty Reduction in Ethiopia and Uganda. http://ftepr.org/publications/. Accessed on March 13th 2015; Tsanga R., Lescuyer G., Cerutti P. O. (2014) 'What is the role for forest certification in improving relationships between logging companies and communities? Lessons from FSC in Cameroon' in, Internationional Forestry Review, 16,1, pp. 14-22. 
economic activity transnationally on a range of social and environmental issues. Their regulatory activities affect economic actors throughout the supply chain and generate an impact on trade patterns. Although some of these initiatives are governmental, though voluntary, in nature most of them are private. However, how useful is it to categorize them as private? In the next sections we explore this question and argue that the distinction between private and public is not straightforward. There is no distinct public sphere of regulation or private sphere of regulation. They, to a certain degree overlap and standards move from public intro private spheres and back again. We substantiate this argument by looking at two units of analysis, the standards and policies pursued by governments.

First, on the level of the standards themselves the distinction between private and public fades because standards typically 'travel' between private and public spheres. Before we elaborate this it is important to note that standards have different levels of precision in the context of vss. In vss standards are typically nested in which you first find general 'standards' or principles, which then are further specified into specific indicators, which can be measured. The latter is necessary in the context of audit protocols, which are one of the main monitoring instruments. For example, the Fair Labour Association has a code of conduct which consists of nine standards: employment relationship, nondiscrimination, harassment of abuse, forced labor, child labor, freedom of association and collective bargaining, health, safety and environment, hours of work and compensation. These standards are then subdivided in many more specific standards. For example, for compensation there are 19 sub-standards such as standards on pay statement or minimum wage which are in turn subdivided in another set of even more specific standards which in addition can vary between countries.

If one looks at the level of standards one can observe that many 'private' standards actually heavily rely and incorporate 'public' rules and standards. Many private standards integrate existing international rules and agreements, often developed in a multilateral context in their set of rules and standards. Often these international rules and standards have been ratified by countries and are incorporated in national legislation. In this way, they integrate public rules and standards in a private set of procedures. Take the example of the Forest Steward Council which bases its transnational regulatory on ten general standards of which two explicitly refer to public international law. The 
first FSC rule requires that standard-takers comply with all laws, regulations, treaties, conventions and agreements. This means that the standards which are developed in the context of the FSC should adhere to provisions included in inter alia the Convention on Nature Protection and Wild Life Preservation in the Western Hemisphere, Convention Concerning the Protection of the World Cultural and Natural Heritage, Convention on International Trade in Endangered Species of Wild Fauna and Flora (Cites), Convention on Biological Diversity (UNCED), Framework Convention on Climate Change, (UNCED) and International Tropical Timber Agreement. ${ }^{24}$ Principle 4 of the FSC refers to worker's rights and the conventions by the ILO including the 1998 Declaration on Fundamental Principles and Rights at Work. This Declaration on Fundamental Principles and Rights at Work covers the core rights and standards laid down in four principles and eight conventions. These principles are (1) freedom of association and the effective recognition of the right to collective bargaining, (2) elimination of all forms of forces or compulsory labor, (3) effective abolition of child labor and (4) elimination of discrimination and respect of employment and occupation. This Declaration is universal and in principle applies to all states. States that have not ratified one or more of the conventions have to report on actions taken towards ratification.

This reliance on existing international agreements and conventions can actually imply that some international agreements are enforced in countries which have not ratified them such as for example the United States with regard to the Convention on Biological Diversity or other countries which have not ratified ILO conventions. In this way, vss sometimes bypass sovereign states and enforce international rules domestically.

vss do not only enforce public international law but also closely interact with national legislation. Basso et al. ${ }^{25}$ analyze the interaction between vss and the enforcement of existing national (Brazilian) legislation. They start with the observation that Brazil has fairly elaborated and complete

24 Marx, A. \& Becault, E. \& J. Wouters (2012) 'Private Standards in Forestry: Assessing the legitimacy and effectiveness of the Forest Stewardship Council', in Marx, A. et al. (eds) Private Standards and Global Governance. Edward Elgar.

25 Basso V. M. \& Vanessa Maria; Jacovine, Laércio Antônio Gonçalves; ALVES, Ricardo Ribeiro and Nardelli, Áurea Maria Brandi (2012) Contribution of forest certification in the attendance to the environmental and social legislation in Minas Gerais State. Rev. Árvore [online], vol. 36, n. 4, pp. 747-757. ISSN 0100-6762. http://dx.doi.org/10.159o/So10o67622012000400016; Basso V. M., Jacovine L. A. G., Alves R. R., Valverde S. R., da Silva F. L., Brianezi D. (2011) 'Evaluation of the influence of forest certification in compliance with environmental legislation in forest plantations' in, Revista Arvore, 35, 4, pp. 835-844. 
environmental and labor legislation, but is confronted with difficulties of effective enforcement. The study aimed to determine the contribution of private forest certification to strengthen compliance with environmental legislation in the management forest units of plantations. They analyzed the degree to which certified entities complied with existing legislation. Overall, they found that certified forests better comply with national legislation, which could be expected on the grounds that FSC integrates existing national legislation in its standard-setting and standard-enforcement procedures. They also found some non-compliances, which were related to environmental and labor legislation. The non-conformance in relation to environmental legislation was mostly related to problems with the Permanent Preservation Areas legislation and the Legal Reserve requirements in Brazilian law. Also in relation to labor legislation they reported non-compliance with regulatory norms concerning health and safety at work. However, they also noted that the certification process did spot these non-compliances and required corrective actions in order to maintain certification. This study shows that vss contributes to the further enforcement of existing national legislation in forest management units and that also public national legislation is integrated in private standards.

What this shows is that many of these standards are embedded in national or international legislation. In this way, government or intergovernmental regulation forms the framework in which the private standard-setting process takes place. What emerges is not so much a difference between public and private but a standard-setting process in which private actors further operationalize and refine public standards. This does not preclude that in some cases this interpretation and transformation of standards feeds back into the public regulatory framework such as in the case of organic regulation. ${ }^{26}$ Regulatory governance scholars have for long recognized that standard-setting is a highly political process in which not only governmental actors play a role but many non-governmental ones. ${ }^{27}$ In addition, standards are not made in one regulatory arena but in several. Ansell and Balsiger ${ }^{28}$ refer to the idea of circuits of

26 Winickoff, D. \& K. Klein (2011) 'Food Labels and the environment: towards harmonization of EU and US organic standards', pp. 229-248, in, Vogel, D. \& J. Swinnen (eds) Transatlantic Regulatory Cooperation. The Shifting Roles of the EU, the us and California. Cheltenham: Edward Elgar.

27 Majone, G. (1998) 'Europe's 'Democratic Deficit': The Question of Standards', in European Law Journal, 4, 1, pp. 5-28.

28 Ansell, C. \& J. Balsiger (2011) 'Circuits of regulation: transatlantic perspectives on persistent organic pollutants and endocrine disrupting chemicals', pp. 180-199, in, in, Vogel, D. \& J. Swinnen (eds) Transatlantic Regulatory Cooperation. The Shifting Roles of the EU, the us and California. Cheltenham: Edward Elgar at p. 181. 
regulation, which captures the idea that regulation takes place through the interaction of separate but overlapping regulatory arenas. These circuits have a horizontal (travelling between regulatory arenas, public and private ones) and vertical dimension (travelling between levels of governance). In the case of vss the overarching standards often originate from public legislation and then get further specified through a process of private decision-making. In this way, many of the standards in vss are certainly not entirely private.

\section{$4 \quad$ Public Policy and Private Standards: Two Separate Worlds?}

vss also interact in many ways with governmental policy. Several efforts have been undertaken to categorize the different measures through which public authorities interact with vss. ${ }^{29}$ These typologies reflect the diverse possibilities of interaction and indicate that government actions are often instrumental in stimulating and promoting the adoption of vss. The support of governments for vss has been documented in several occasions. Both in setting up vss and promoting adoption governments, or government agencies, have played and still play a role. Governments have been instrumental in setting up vss schemes. In the forest sector governments have supported the creation of vss programs. ${ }^{30}$ The Malaysian government recently supported the Malaysian

29 Bendell J., Miller A., and Wortmann K. (2011) 'Public policies for scaling corporate responsibility standards Expanding collaborative governance for sustainable development', Sustainability Accounting, Management and Policy Journal, 2 (2): 263-293; Carey, C. and Guttenstein E., (2008) 'Governmental Use of Voluntary Standards: Innovation in Sustainability Governance' London: IsEAL Alliance; Vermeulen, W. J. V., Uitenboogaart, Y. J., Pesqueira, L. D. L., Metselaar, J. and Kok, M. T. J. (2011) 'Roles of Governments in MultiActor Sustainable Supply Chain Governance Systems and effectiveness of their interventions-An Exploratory Study' Bilthoven: Netherlands Environmental Assessment Agency (PBL); Wood, S. (2003) 'Environmental Management Systems and Public Authority in Canada; rethinking Environmental Governance', Buffalo Environmental Law Journal 10: pp. 129-210; Wood, S. (2005) 'Three Questions about Corporate Codes: Problematizations, Authorizations and the Public/Private Divide' in W. Cragg (ed.) Ethics Codes: The Regulatory Norms of a Global Society? Aldershot: Edward Elgar Press.

30 Cashore, B., Auld, G., Newsom, D. (2004) Governing Through Markets. Forest Certification and the Emergence of Non-state Authority New Haven: Yale University Press; Cashore, B., van Kooten G. C., Vertinsky I., Auld G., Affolderbach J. (2005) 'Private or self-regulation? A comparative study of forest certification choices in Canada, the United States and Germany' in, Forest Policy and Economics, 7, 1, pp. 53-69. 
Sustainable Palm Oil certification scheme, ${ }^{31}$ which is a competitor to the Roundtable on Sustainable Palm Oil. International Sustainability and Carbon Certification was developed with support from the German Federal Ministry of Food, Agriculture and Consumer Protection, while the process leading to the setting of the Netherland Technical Agreement (NTA) 8080 was supported by the Dutch government. Van der Heijden ${ }^{32}$ analyzed 40 voluntary environmental programmes (VEPS) that are active in the building sector in Australia, the Netherlands, Singapore and the United States. Many of these vEPS could be considered vss for the building sector. He finds that governments are involved in almost all of these VEPs (95 per cent) and take up a diversity of roles but most importantly the role of initiating and setting up VEPs.

Also in fostering adoption governments provide incentives and in the case of developing countries financial and technical assistance. One can find many examples of international donors engaging with vss. At present, international donors such as DIFID, USAID, World Bank, Belgian Technical Cooperation, GIZ, provide financial as well as technical support to various vss setting bodies such as Fairtrade, Global Gap, Rainforest Alliance and UTz. Examples include the support of $4 \mathrm{C}$ by Flemish International Cooperation Agency; the Cotton Initiative by Swedish Development Cooperation, Ethical Tea Partnership by Danish Development cooperation and GiZ; Fair Trade by a host of donors including Belgian development cooperation, DFID, Irish Aid, Norwegian Development Cooperation, GiZ, and Agence Française de développement; GlobalGAP by GiZ; Rainforest Alliance by US AID and UTZ certified by Irish Aid. In some cases specific programs are developed to further support the adoption of vss such as European Banana Support Programme in Jamaica. ${ }^{33}$ This is a 3.5 MEUR investment in rural development in Jamaica in order to improve the competitiveness of the banana industry. Under this programme several projects have been financed which support Jamaican farmers to comply with vss such as Global Gap and Fair trade. Many other donors are taking similar initiatives.

However, more significant from a regulatory or policy perspective, vss are increasingly becoming part of regulatory actions of governments. If one shifts the lens to public policy-making and governance arrangements as a unit of

31 Sharma, M. (2013) 'Sustainability in the Cultivation of Oil Palm-Issues \& Prospects for the Industry' Journal of Oil Palm \& the Environment 4.

32 Van der Heijden, J. (2015) 'What Roles are There for Government in Voluntary Environmental Programmes?', in, Environmental Policy and Governance Dor: 10.1002/eet.1678. Banana program http://ec.europa.eu/delegations/jamaica/projects/list_of_projects/ 18440_en.htm. 
analysis one can observe that vss in several instances complement public policy strategies and constitute an inherent part of public policy arrangements. In other words, the shift from government to governance not only implies that other actors involved in the regulatory or governance process but that governments on purpose or in the design of governance take these private initiatives on board. Hence, they become an integral part of 'public' governance. This happens in several ways.

\subsection{Public Procurement Policies}

One way in which vss are integrated in legislation and policies is through sustainable public procurement (SPP) policies. SPP is an increasingly widespread practice that has been consolidated in policy frameworks at several institutional levels, particularly in Europe. Analyzing SPP frameworks provides insight in governments' expectations towards vss. In this sense, Gulbrandsen notes that the potential of vss depends on 'how and whether they will act synergistically with government rules. ${ }^{34}$ Given the large quantity of their purchases the impact of the integration of vSS in SPP is potentially vast. ${ }^{35}$ In most countries, the share of public procurement represents anything between $10 \%$ to $25 \%$ of Gross Domestic Product. ${ }^{36}$ SPP practices include public authorities demanding that wood products are manufactured from legally harvested or sustainable timber, that public buildings meet ecological standards, that clothing for state employees is made in a healthy and childfree labor environment, or that coffee served is produced in fair conditions.

The elaboration of SPP policies does not imply a straightforward adoption of vss by governments. In the majority of legal frameworks for public procurement, the principle of equal treatment and non-discrimination prohibits contracting authorities to choose or prefer a trademark or label. This would imply discrimination as it means excluding certified products and services without the preferred certificate. Hence, demanding that goods or services are certified by a specific vss is prohibited within for example the EU framework for

34 Gulbrandsen, L. H. (2012) 'Dynamic governance interactions: Evolutionary effects of state responses to non-state certification programs', Regulation and Governance p. 17.

OECD (2008) 'Promoting Sustainable Consumptions—Good Practices in OECD Countries' Paris: Organization for Economic Cooperation and Development. http://www.oecd.org/ dataoecd/1/59/40317373.pdf.

36 UNEP (2011) 'Marrakech Task Force on Sustainable Public Procurement led by Switzerland. Activity Report' Paris: United Nations Environmental Programme, Division of Technology, Industry and Economics. 
public procurement. ${ }^{37}$ However, the use of vss in SPP is indirect: through (a) the integration of vss sustainability criteria into public tenders (ie operationalized private standards flow back into public tenders); or (b) the referencing of vss as a 'proof of compliance' in public tenders.

Concerning (a), when including environmental and social dimensions in SPP, contracting authorities have often relied on the sustainability criteria developed by vss. ${ }^{38}$ Several European governments have elaborated SPP guidance instruments for procurement officers, which identify the environmental, social and ethical criteria that can be included in a public tender. These tools transpose the specifications or criteria developed by vss into a set of national criteria in order to streamline the use of SPP and avoid litigation. To ensure these requirements are not too narrow or 'vss-specific' (i.e. discriminatory), government agencies in a number of EU countries have established layered criteria-setting processes for different product groups. Through these processes, government agencies aim to adapt the national sustainability criteria to the availability of sustainable/certified products and services in the domestic market. Such processes are often led or complemented by stakeholder consultations, which bring together representatives from the private sector, NGOS, government officials, and academics. For specific sectors, notably timberrelated products, national centres of expertise have been established to assist government bodies in defining adequate criteria and evaluating or benchmarking vss performance. These government bodies accredit certain vss and exclude other vss for government purposes. Examples are the UK's Central Point of Expertise on Timber (CPET) and the Timber Procurement Assessment Committee (TPAC) in the Netherlands.

Concerning (b), in daily procurement practice, vss serve as proof (indicators) of social and environmental performance and are used as shorthand to assess the bidder's credentials. As noted before, demanding a specific vss is not possible within the legal frameworks, but contracting authorities do have a certain degree of flexibility by referring to particular certification schemes as a non-exclusive proof of compliance. Interesting in this context are the debates concerning the integration of fair trade criteria in public tenders. This has long remained a point of contention, illustrated by the case brought before

37 EC (2010) Buying Social: A Guide to Taking Account of Social Considerations in Public Procurement Luxembourg: European Commission, Publications Office of the European Union.

38 D'Hollander, D. \& A. Marx (2014) 'Strengthening Private Certification Systems through Public Regulation: The Case Of Sustainable Public Procurement', in, Sustainability Accounting, Management and Policy Journal, 5, 1, pp. 2-22. 
the European Court of Justice between the Commission and The Netherlands concerning specific references to the criteria of the E Ko label and the Max Havelaar Label in a public tender issued by the Province of Groningen. ${ }^{39}$ The ECJ's ruling confirmed fair trade principles, and a reference to labels, can be included in public tenders as an award criterium.

The integration of vss criteria into SPP frameworks can be seen as the internalization of 'privately developed' standards and criteria by governments. The use of vss as proof of compliance can be considered a direct form of how public authorities use vss as verification mechanisms in procurement activities. SPP policies exemplify how governments "combine public sector regulation with private sector standard setting to arrive at a mixed regulatory regime," (Bendell, 2011, p. 38). It should be noted that the integration of vss in SPP influences also the procedures and functioning of vss. According to Overdevest, ${ }^{40}$ SPP policies used by governments effectively stimulate greater transparency and performance in the forestry certification sector. Gulbrandsen also shows how the initial non-approval of certain forestry schemes by the UK's Central Point of Expertise on Timber (СРET) has led these schemes to reform and adjust their internal functioning in line with the demanded requirements. Public assessments carried out in the framework of SPP policy contributed to an upward harmonization of the institutional design of the different national PEFC schemes. ${ }^{41}$

\subsection{Integration of vss in Regulatory Processes}

Policy initiatives also integrate vss in the design of regulatory processes and public policies. One case in point is the EU Timber regulation (EU Regulation 995/2010) on the prohibition of selling illegally harvested timber on the European market. According to this regulation importers of timber products must provide proof that the timber was legally harvested, that is, attestation that the forest products originate from legally harvested forests (ie legality verification). Being certified according to a forest-related vss does not automatically imply that you comply with regulation or as evidence of legality. The EU timber regulation requires that operators need to have a due diligence system in place which consists of three elements, information, risk assessment and

39 ECJ (2012) 'Judgment of the Court (Third Chamber) of 10 May 2012-European Commission v Kingdom of the Netherlands' European Court of Justice, Case C-368/10.

40 Overdevest, C. (2010) 'Comparing Forest Certification Schemes: The Case of Ratcheting Standards in the Forest Sector' Socio-Economic Review 8: 47-76.

41 Gulbrandsen, L. H. (2012) 'Dynamic governance interactions: Evolutionary effects of state responses to non-state certification programs', Regulation and Governance p. 11. 
risk mitigation. A due diligence system can be developed by a company or a recognized 'monitoring instrument'. Currently, the Commission has recognized a limited number of monitoring organisations. They include the typical certifiers such as Bureau Veritas, SGS UK and NEPCon. However, vss play a key role in this due diligence system, especially in steps 2 (risk assessment) and 3 (risk mitigation). Article 4 of the regulation on risk assessment and risk mitigation stipulates that, "Certification or other third-party verified schemes [...] may be taken into account in the risk assessment and risk mitigation procedures".

In other words, the fact that an operator is certified by a vss does not mean that a due diligence system is not required. However, vss provide a way to fulfil parts of the due diligence requirements of the EU regulation (ie proof of compliance). For example, NEPCon one of the recognized monitoring organisations by the European Commission, has developed a LegalSource standard and due diligence guidelines to assess and verify an operator (timber importer). Part of this standard and set of guidelines address the due diligence part of risk assessment and mitigation. If the risk assessment identifies a negligible risk (lowest level of risk) no further action is required and an operator complies. The NEPCon documents clearly recognize FSC as a vss as part of risk assessment and mitigation. (NEPCon Legal Source Document ${ }^{42}$ ) This recognition of FSC certification shows the 'competitive' advantage of being certified in order to fulfil the requirements of the EUTR. Hence, in the case of EUTR there is a nested private standards requirement in which private actors assess due diligence of operators on the basis of private standards and guidelines on legality which in turn refer to private standards (vss) to address elements of the due diligence system of an operator.

However, in some cases the integration of vss in legislation is more direct and legislation directly recognizes vss. For example, of the $2009 \mathrm{EU}$ Renewable Energy Directive (RED) (2009/28/EC) and the EU Fuel Quality Directive (FQD) (2009/30/EC), RED requires 20 per cent of energy use in the EU to come from renewable sources by 2020, while FED obliges suppliers of fossil fuel to gradually reduce greenhouse gas emissions. Under RED, the Commission set up an accreditation system for voluntary standards in order to proof compliance of biofuel providers with the directive. The list currently comprises 19 vss including inter alia International Sustainability and Carbon Certification, BonSucro, Round Table on Responsible Soy, Roundtable of Sustainable Biofuels, Red

42 NEPCon Legal Source Document 2013 Available at: http://www.nepcon.net/sites/default/ files/library/LS-02-LegalSource-Standard-V2-1.pdf. 
Tractor and Roundtable on sustainable Palm Oil. ${ }^{43}$ As Ponte and Daugbjerg and Schleifer point out this type of hybrid governance is based on deep and mutual dependence and interconnection between public and private elements. ${ }^{44}$

The integration of vss in public policies can be expected to further develop, especially in the context of trade related policies and an expanding 'governance through trade agenda.' ${ }^{45}$ There are already some who advocate the integration of sustainability standards in the EU Generalised System of Preferences (GSP) scheme. In a report by the Deutsche Gesellschaft für Internationale Zusammenarbeit on behalf of the German Federal Ministry for Economic Cooperation and Development on 'Tariff preferences for sustainable products: an examination of the potential role of sustainability standards in generalized preference systems based on the European model (GSP)' proposals are being put forward to further support the adoption of vss through a system of state recognition and the extension of the existing trade policy tools for sustainable development. ${ }^{46}$

The GSP of the EU makes preferential market access conditional upon adherence to specific norms. GSP is a set of rules granting preferential EU market access to exporters from developing countries through lower duties on some or all of their exports to the EU. In October 2012, EU Regulation 978/2012 updated the Union's GSP Scheme with the following objectives: to focus help on those countries truly in need; to strengthen the incentives for good governance and sustainable development known as 'GSP+'; and to make the scheme more transparent, stable and predictable. The current system of GSP consists of three parts: (1) the standard GSP which benefits 176 countries, GSP+ (special incentives for sustainable development and good governance) which grants additional preferences to currently 16 countries which inter alia have ratified

43 European Commission (2015) Recognized Voluntary Schemes under Renewable Energy Directive http://ec.europa.eu/energy/en/topics/renewable-energy/biofuels/voluntaryschemes.

44 Ponte, S. and C. Daugbjerg (2015)"Biofuel Sustainability and the Formation of Transnational Hybrid Governance", in, Environmental Politics, Vol. 24, No. 1, pp. 96-114; Schleifer, P., (2013) Orchestrating sustainability: The case of European Union biofuel governance. Regulation and Governance, 7, 4: 533-546.

45 Damro, Chad (2012), 'Market Power Europe', Journal of European Public Policy 19, 5: 682699; Meunier, S. \& K. Nicolaïdis (2006) 'The European Union as a conflicted trade power', 13Journal of European Public Policy, pp. 906-925.

46 Schukat, P. Rust, J. and J. Baumhauer (2014) Tariff Preferences for Sustainable Products: A Summary', pp. 419-430, in Schmitz-Hoffmann, C. et al. (eds.), Voluntary Standard Systems, Natural Resource Management in Transition. Berlin: Springer-Verlag Berlin Heidelberg, at p. 420 . 
and implemented 27 international conventions and the Everything but Arms Programme for the 50 least developed countries. The possible integration of VSS in GSP would further mix-in vSs in trade-related policies.

However, not only the EU is integrating vss in trade policies. Many developing countries and middle-income countries are recognizing vss in trade policies. In a speech in The Hague, Jamaica's Minister of Agriculture, Labour and Social Security, stated that GLOBALG.A.P. certification is from 2015 a requirement for all Jamaican farmers wishing to export their fresh produce to Europe. This is a part of the Food Safety Modernization Act of 2011. In addition, the Jamaican government is planning to spend some $\$ 100$ million in the 2015/16 financial year to support certification and promote export.. Or take the example of Vietnam. As Putzel ${ }^{47}$ (2012) shows the Vietnamese government has, since 1992, implemented far reaching policies and programs to increase the country's tree cover by promoting plantation forestry inter alia to promote export, provide environmental services and alleviate rural poverty. This policy was set against a background of promoting sustainable forestry. More than 4 million ha of forests were assigned to households and rural cooperatives through forestland reallocation or management contracts. The idea was to involve these households and cooperatives in timber based supply chains. In addition, in the last decade, with Vietnam's economic liberalisation policies, the timber processing industry has shifted from State-owned enterprises to private companies. By 2008, the timber-processing sector had expanded into a $\$ 3$ billion industry, one of Vietnam's top live export sectors and a major source of demand for logs and sawnwood. In this context several small forest owners were seeking FSC certification to enter timber supply chains and access export markets, aided by several public and private donors including the Vietnamese government and Worldbank. Hoang et $\mathrm{al}^{48}$ assessed these policies. They show that FSC has brought new opportunities, such as price premiums, access to trade networks and markets, but that this was only possible through government support for the adoption of standards. Hoang et al. clearly show that there is a heavy dependency on and involvement of the government (and other donors) in adopting vss. This example shows how governments make adoption of vss a component of their industrial (and export oriented) policies.

47 Putzel L., Dermawan A., Moeliono M., Trung L. Q. (2012), Improving opportunities for smallholder timber planters in Vietnam to benefit from domestic wood processing in, International Forestry Review, 14, 2, pp. 227-237.

48 Hoang H. T. N., Hoshino S., Hashimoto S. (2015) 'Forest stewardship council certificate for a group of planters in Vietnam: swот analysis and implications' in, Journal of Forest Research, 20, 1, pp. 35-42. 
In a broader scheme of things, what do these examples tell us? What drives this integration of private standards into public policy is fourfold. One is a movement towards the regulatory operationalization of due diligence requirements. Due diligence requirements in legislation were introduced in the food sector following several food crises. The food crises showed that markets had become increasingly globalized which leads to difficulties in tracing the origins of such products. As a result, it had become much more difficult for single governments to keep track of the range of products present on their domestic markets, and to keep up with the assessment of all the risks associated therewith. As a result, governments changed their regulatory approach in which supermarkets bear a specific responsibility. As the final link between the food producer and the consumer, supermarkets bear a default responsibility for the entire food. As a result they had to develop standards and tracking system throughout their supply chain. An early example of such regulatory design is the due diligence requirement contained in the U K Food Safety Act (UKFSA) of 1990, which provides that food retailers can escape liability for non-compliance with food safety laws if they can demonstrate that they have taken all precautions in this regard. The possibility of being held liable for food safety issues did prompt a response from the food industry, resulting in the development of many different vss. ${ }^{49}$ Mirroring the UKFSA, the EU Food Law Regulation of 2002 also provides for a quite stringent responsibility threshold for commercial actors involved with food products. This regulatory approach, which outsources risk assessment, risk mitigation, monitoring and reporting, is diffusing. Requirements for due diligence are becoming more widespread and take on diverse forms such as, as a matter of regulatory compliance or as part of a transparency requirement. De Schutter et al ${ }^{50}$ found more than 100 examples of due diligence regimes in more than 20 countries. In many cases, vss act as proof of due diligence measures.

Second, governments, in an interconnected world, have increasingly sought to govern behind their borders and govern through trade as noted above. In the case of biofuels the EU needs vss to reach beyond its borders. The fact that

49 Food and Agriculture Organization (2007) Private Standards in the United States and European Union Markets for Fruit and Vegetables-Implications for Developing Countries. FAO Commodity Studies No. 3. Rome: FAO; Henson, S. and J. Humphrey (2012) 'Private Standards in global agri-food chains', pp. 98-113, in Marx et. al (eds.) Global Governance and Private Standards. Interdisciplinary Perspectives. Cheltenham: Edward Elgar.

5o De Schutter, O. et al. (2012) Human Rights Due Diligence: the Role of States report for the International Corporate Accountability Roundtable. Available at: http://accountabilityroundtable.org/analysis/hrdd/. 
sustainability cannot be observed in products when they cross the Eu border, but are largely based on production process characteristics means that sustainability has to be assessed at the place of production. ${ }^{51}$ Since vss provide this type of monitoring and assessment capacity they offer a regulatory service, which is absent for the $\mathrm{EU}$. In this way, vss close a regulatory gap that a government cannot close by itself. They enable governments to transcend the scope of their national regulatory capacities and work towards global sustainability goals. vss do not only set standards, but more importantly also enforce (monitoring and sanctioning) them and hence provide capacity to enforce regulation. In this way they solve a major governance problems for sovereign states, namely the issue of monitoring and sanctioning. ${ }^{52}$

Third, vss are becoming important tools in export promotion. Given the enormous increase in international trade over the last five decades (3o fold increase according to Hoekman ${ }^{53}$ ) and the importance of export for economic development several governments have developed policies which link vss to export promotion as is illustrated by the cases of Jamaica and Vietnam. This integration of vss in export promotion policies can be expected to further develop and diffuse.

Finally, vss offer some other advantages. First, they allow governments to reach policy objectives without having to commit additional costs and resources to reforming the national regulatory framework and setting up the necessary verification mechanisms. vss become a budget-neutral improvement and essential component of regulatory action. ${ }^{54}$ Second, they allow governments to bring social and environmental criteria into the economy without forcing them on the private sector but gradually introducing them and gradually making them semi-voluntary or mandatory in time through supportive policies. vss allow governments the flexibility to play in the dynamic space between hard law and soft law, mandatory and voluntary regulation ${ }^{55}$ and create a dynamic whereby actors continuously create policy learning and possibly

51 Ponte, S. and C. Daugbjerg (2015)"Biofuel Sustainability and the Formation of Transnational Hybrid Governance", in, Environmental Politics, Vol. 24, No. 1, pp. 96-114;

$5^{2}$ This is not to argue that there are no problems with monitoring formats of vss which are based on auditing approaches. For a discussion see Marx and Wouters (2015).

53 Hoekman, B. (2014) Supply Chains, Mega-Regionals and Multilateralism. A Road Map for the WTO. London: CEPR Press at p. 15 .

54 Bendell J., Miller A., and Wortmann K. (2011) 'Public policies for scaling corporate responsibility standards Expanding collaborative governance for sustainable development', Sustainability Accounting, Management and Policy Journal, 2 (2): 263-293.

55 Koenig-Archibugi M. (2004) 'Transnational corporations and public accountability', Government and opposition: an international journal of comparative politics 39 (2): 234-259. 
a ratcheting up of standards. ${ }^{56}$ Third, the increasing proliferation, specialization and diversification of vss allow governments to better meet the differing sectoral and regional demands and hence allow for more tailor-made approaches suitable to standard-takers. The significant number of accredited vss under the Biofuel directive (19 in total-see above) shows that the European Commission wants to use the diversity of vss in their regulatory approach. Fourth, vss offer the potential to promote leaders and sanction non-compliance of standard-takers without using far-ranging measures which would hurt an entire sector or economy (suspension under GSP or trade sanctions under a trade agreement). ${ }^{57}$

In sum, vss complement existing policies in several ways and are becoming an intrinsic part of policy approaches. In this way they blend purposefully into different governance arrangements and policy mixes. Lambin et al. ${ }^{58}$ (2014), looking at land use policies, provide many detailed examples of this blending. The different policy instruments they identify for land use planning are public command and control regulation, payments for environmental services, moratoria, eco-certification, commodity roundtables and geographical indications. The latter three fall under the broad category of vss. Each of these policy instruments has a different target unit (area, commodity or a combination), policy mechanism (mandatory rules, incentives, market exclusion) and enforcement (surveillance and auditing). They argue that land use is increasingly regulated through various mixes of these policy instruments leading to hybrid forms of governance. Researchers focusing on transnational business governance put forward similar arguments. Eberlein et al. ${ }^{59}$ also observe a proliferation of nonstate regulatory approaches to business conduct, including vss, and note that they increasingly interact with one another but also with state-based regimes and regulatory approaches. In other words, vss are (becoming) an integral part of public policies making it very difficult to distinguish public from private.

$5^{6}$ Overdevest, C. and J. Zeitlin (2012) 'Assembling an experimentalist regime: Transnational governance interactions in the forest sector', Regulation and Governance.

Schukat, P. Rust, J. and J. Baumhauer (2014) Tariff Preferences for Sustainable Products: A Summary', pp. 419-430, in Schmitz-Hoffmann, C. et al. (eds.), Voluntary Standard Systems, Natural Resource Management in Transition. Berlin: Springer-Verlag Berlin Heidelberg.

58 Lambin, Eric F., Patrick Meyfroidt, Ximena Rueda, Allen Blackman, Jan Börner, Paolo Omar Cerutti, Thomas Dietsch, Laura Jungmann, Pénélope Lamarque, Jane Lister, Nathalie F. Walker, and Sven Wunder (2014) "Effectiveness and Synergies of Policy Instruments for Land Use Governance in Tropical Regions." Global Environmental Change 28 129-40.

59 Eberlein, B., Abbott, K., Black, J., Meidinger, E., Wood, S. (2013) 'Transnational Business Governance Interactions: Conceptualization and framework of analysis', Regulation and Governance, published online 22 Juli 2013 http://onlinelibrary.wiley.com/doi/10.1111/ rego.12030/abstract. 
vss are regarded as having passed the 'proof of concept' phase $\mathrm{e}^{60}$ and now have a considerable degree of credibility as a governance instrument. The latter is also partially a result from the fact that they gain legitimacy by relying on a set of public international standards and international rules. They also constitute an interesting case study to assess the public-private distinction in the context of standard setting since they are a leading example of private standard setting.

The above discussion shows that the distinction between public and private standards, from a regulatory or policy perspective, is not very relevant if one does not solely focus on the legal status of an organization involved in standard-setting and enforcement. Public and private increasingly 'co-regulate', forms hybrid forms of governance, complement and supplement each other and interact with one another. In addition, these private standards integrate to a degree international and national public legislation. The trends outlined above will continue to develop. This in a context of a proliferating and diversifying field of vss in which vss differ significantly in how they are designed and operate ranging from 'greenwash' types of initiatives to elaborated regulatory mechanisms with clear rules and procedures on standard-setting, conformity assessment, transparency and dispute settlement. ${ }^{61}$ A key issue will become on how to formally and legally recognize or even regulate vss. In this context some interesting developments are unfolding such as the formal recognition of vss under the renewable energy directive of the European Commission and governmental-led but independent committees evaluating vss in the context of public policies such as the Timber Procurement Assessment Committee of the Netherlands. This move towards formal recognition of vss will also continue to develop. Such a formal recognition, based on at least the content of standards (embedded in international and national legislation) and the process of certification (ie system requirements concerning accreditation and certification processes (ISO standards, wTо твт Code of Good Practice and ISEAL Codes of Good Practice)) will contribute to a further integration of vss in public policies making the public-private distinction oblivious.

6o UNCTAD (2011) 'World Investment Report 2011: Non-equity Modes of International Production and Development' Geneva: United Nations Conference on Trade and Development.

61 Marx, A. (2014) 'Varieties of Legitimacy: A Configurational Institutional Design Analysis of Eco-labels' in, Innovation: European Journal for Social Science Research, 26, 3, pp. 268-287. 